\title{
РЕЦЕНЗИЯ НА КНИГУ: ЮРИСДИКЦИОННЫЕ КОНФЛИКТЫ ПРИ ТРАНСГРАНИЧНОЙ ПРЕСТУПНОСТИ. СРАВНИТЕЛЬНО-ПРАВОВОЕ ИССЛЕДОВАНИЕ МЕЖДУНАРОДНОГО ПРАВА / ОТВ. РЕД. АРНДТ ЗИНН. ОСНАБРЮК: УНИВЕРСИТЕТСКОЕ ИЗДАТЕЛЬСТВО, 2012. - 620 С.
}

\begin{abstract}
Аннотация. В рецензии анализируются результаты исследования юрисдикиионных конфликтов, возникающих при расследовании и судебном рассмотрении транснациональных актов преступного поведения. Характеризуются особенности действия территориального и других приниипов, правовая регламентаиия экстрадиции. Освещаются модели, пригодные для регулирования юрисдикиионных конфликтов в рамках Европейского Союза и других государствах. Показано, что действующие в настоящее время акты Европейского парламента о разрешении компетенционных конфликтов в отношении расследования преступлений и наказания преступников, совершающих противоправные уголовно-наказуемые деяния на территории нескольких государств и международные конвенции о борьбе с транснациональной, организованной $и$ иными видами преступности, оставляют многие вопросы нерешенными. В рецензируемой книге исследованы международно-правовые предпосылки использование уголовного права в борьбе с транснациональной преступностью, коллизии национального уголовного права, возможности разрешения конфликтов, конституционные основы, особенности уголовно-правовых норм, приниипы и способы решения вопросов о подведомственности и подсудности. Анализируются модельные проекты регламентаиии механизма разрешения юрисдикиионных конфликтов и обосновываются предложения о разработке проекта Рамочного решения Европейского Совета о передаче уголовного судопроизводства.
\end{abstract}

Ключевые слова: Конвенция, конституция, конфликт, юрисдикция, преступность, принцип, право, уголовный закон, уголовное преследование, суд.

Abstract: This review analyzes the results of the research on the jurisdictional conflicts that emerge during investigations and trials of transnational acts of crime. It characterizes the aspects of the work of the territorial and other principles including legal process of extradition. Emphasis is made on the models that would be useful for regulation of the jurisdictional conflicts within the EU and other countries. The author demonstrates that the current acts of the European Parliament and the international conventions on the fight against transnational and organized crimes leave a lot of questions unaddressed with regards to resolution of competential conflicts pertaining to investigations of crimes and punishment of those who committed crimes across several countries. The book being reviewed analyzes international legal prerequisites of implementing the criminal law in the fight against transnational criminality; collisions of national criminal law; ability to resolve conflicts; constitutional foundations; aspects of the norms of criminal law; model projects of regulating the mechanism for resolving jurisdictional conflicts.

Keywords: Convention, constitution, conflict, jurisdiction, criminality, law, criminal law, criminal prosecution, trial. 


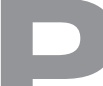
абота представляет собой коллективную монографию, авторами которой являются ученые-специалисты в области уголовного права из различных стран, как входящих в Европейский Союз (Германия, Австрия, Венгрия, Франция, Дания, Великобритания, Италия, Эстония, Польша, Испания), так и не являющихся его членами (Бразилия, Россия, США, Швейцария, Япония, Тайвань и Турция). Она опубликована в рамках издаваемой Центром европейского и международного права Университета г. Оснабрюк (ФРГ) серии по результатам исследований в области сравнительного уголовного права - том 4.

В предисловии (с. 9-11) профессора Вальтера Гроппа (Университет г. Гиссен ФРГ) отмечается, что, несмотря на действующие в настоящее время акты Европейского парламента о разрешении компетенционных конфликтов в отношении расследования и наказания преступников, действующих на территории ряда государств, и международные конвенции о борьбе с транснациональной, организованной и иными видами преступности, многие вопросы остаются неясными или вызывают большие сложности при оценке преступных деяний и назначении мер наказания, в первую очередь, связанных с лишением свободы, тем лицам, чья преступная деятельность «переходит» границы нескольких государств. Именно поэтому при поддержке Европейской рабочей группы, Фонда Фрица Тиссена, Округа Оснабрюк, Университета г. Оснабрюк, Макс-Планк Института иностранного и международного уголовного права (Фрайбург-на-Брайсгау, ФРГ) и было организовано исследование, результаты которого представлены в данной монографии. Его целями изначально определялись не только проверка действия территориального принципа ${ }^{1}$, но и укрепление Евроюста,

${ }^{1}$ Комментарий к Уголовному кодексу Российской Федерации. / усиление правовой защиты граждан, разработка проекта европейской конвенции и др. Для этого под руководством директора Центра европейского и международного права Университета г. Оснабрюк профессора А.Зинна был осуществлен соответствующий проект с участием 40 научных работников и практиков, подготовивших 27 обширных докладов, отражающих ситуацию и позиции по данному вопросу в 17 странах, и их соотношение с двумя имеющимися моделями - нынешней, выражающейся в договорной подсудности, и модели, ориентированной на будущее, то есть ориентированной на законодательно определенную подсудность.

Монография снабжена также введением (прологом) А.Зинна (с. 13-17) на немецком и английском языках, в котором он описывает организацию работы исследовательской группы и суть проходивших в течение двух лет дискуссий на промежуточных и итоговой конференции.

Книга состоит из пяти частей. В первой из них, озаглавленной «Основы», содержатся восемь фрагментов (статей), в которых освещены вопросы, являющиеся в целом общими для всех стран-участниц проекта. Среди таких вопросов международно-правовые предпосылки использования уголовного права в случаях транснациональных преступлений; коллизии национального уголовного права - nulla prosecutio transnationalis sine lege; возможность использования международного частного права в качестве примера для применения транснационального уголовного права ${ }^{2}$; правовые возможности Европейского Союза при решении компетенционных конфликтов; значение Рамочного решения Европейского парламента 2009/948 от 30 ноября 2009 г. о предупреждении и разрешении конфлик-

\footnotetext{
${ }^{2}$ Субботина Е.Н. Механизм имплементации международного уголовного права в зарубежных странах и в России. М.: Юрлитинформ, 2012: 216 с.
} 
тов в сфере компетенции при уголовном преследовании; коллизии применения уголовного права в практике; юрисдикционные конфликты при пересекающей границы организованной преступности - примеры из практики. Эти разделы выполнены в основном немецкими специалистами - учеными и практиками, а также участниками проекта, работающими в международных и европейских организациях (Т. Марон и С. Симон, В. Гропп, М. ШмидтКессель, Б. Хекер, Д. Фикарова, Д. Андерс, Х. Бюхлер и Р. Кройцер, Х.Х. Хернфельд). Представленный ими материал не только дает общее представление о сложившейся ситуации в области возникновения и разрешения юрисдикционных конфликтов в современный период, но и убедительно демонстрирует необходимость дальнейшей разработки данной проблематики.

Вторая часть (с.165-500) представляет собой материалы, отражающие законодательное регулирование и практику в различных странах (Бразилия, Дания, Германия, Англия и Уэльс, Эстония, Франция, Италия, Япония, Австрия, Польша, Россия, Швейцария, Испания, Тайвань, Турция, Венгрия, США), проанализированные по единой схеме. Эта - отметим - весьма удачная схема включает информацию о системе правового регулирования в области применения уголовного права, начиная с конституционных основ; характеристику уголовно-правовых норм; обзор закрепленных в законодательстве (конституционном и уголовном) принципов, на которых базируется применение уголовного права (территориальный принцип, активный и пассивный персональный принцип, реальный и универсальный принципы и др. $)^{3}$, подход к пониманию сути юрисдикционных конфликтов, в структуре, элементам

${ }^{3}$ А.Э. Жалиннский. Современное немецкое уголовное право. М.: Проспект, 2004. - 560 с. и стадиям, особенности юрисдикционных конфликтов при расследовании организованной преступности, пути решения вопросов о подведомственности и подсудности. Применительно к российскому праву исследование этих проблем опирается на анализ статей 4, 16, 61 и других Конституции РФ о суверенитете Российской Федерации, приоритетном применении международных норм, принципов, договоров, выдаче лиц, совершивших преступления, а также тех статей УК РФ, в которых определяются основания уголовной ответственности, понятие преступления, принципы уголовного права и, в первую очередь, действие уголовного закона в пространстве и по кругу лиц (ст.11-13 УК РФ). Авторами разделов второй части являются, соответственно, научные работники - представители перечисленных стран и сотрудники Макс-Планк Института иностранного и международного уголовного права (Фабио Роберто Д.Авила, Карин Корнильс и Ван Греве, Лиане Вёрнер и Матиас Вёрнер, Барбара Хубер, Андрес Пармас и Яан Соотак, Жульетта Лело, Луиджи Фоффани, Ренцо Орланди и Стефано Руджери,Кациоши Като и Юкако Сагава, Гудрун Хохмайер, Эва М. Гузик-Макарук. Адам Гурский и Анджей Сакович, Альфред Жалинский и Ольга Дубовик, Кристоф Рингельманн, Мария Жозеф Пифарре де Моне, Хсяо Ю. Ву, Готфрид Плагеманн, Крисцина Каршаи, Стефен Таман.

Таким образом, во второй части монографии дается достаточное полное описание того, каким образом в перечисленных выше странах регулируются вопросы подведомственности и подсудности, экстрадиции и взаимодействия органов следствия и судов в тех случаях, когда преступная деятельность осуществляется субъектами, обладающими гражданством различных государств в отношении лиц, являющихся гражданами различных го- 
сударств, на территории более чем одного государства (либо преступление совершено на территории одного государства, а последствия наступили на территории иного государства), преступник скрылся на территории третьего государства или доходы, полученные преступным путем, поступили лицам, находящимся на территории третьего государства, и т.д. Типичными примерами таких ситуаций и возникающих при этом юрисдикционных конфликтов являются торговля женщинами, принуждение к занятию проституцией, незаконный оборот оружия, наркотиков и проч. Так, гражданин РФ осуществлял вывоз женщин, являющихся гражданами Молдавии и Украины, для «работы»в Арабских Эмиратах, Таиланде, странах EC, передавая их владельцам публичных домов, которые могли быть гражданами иных государств, например, Италии или Франции. Здесь возникает ряд юрисдикционных конфликтов, связанных с материальным и процессуальным уголовно-правовым регулированием. Следственные органы (прокуратура) какого государства должна проводить следственные действия, в компетенцию какого суда входит рассмотрение дела, предусмотрена ли ответственность за такого рода деяния в каждом из затронутых государств, какова эта ответственность, как решаются вопросы о выдаче престуапников, как учитываются в законодательстве разных стран моменты начала совершения преступления, его осуществления, его окончания и наступления преступных последствий и т.д.

Третья часть книги «Сравнительноправовые наблюдения» (с. 501-556) включает тексты на английском и немецком языках, подготовленные А. Зинном в результате сопоставления регламентации применения уголовного права для решения юрисдикционных конфликтов в различных странах. Он приходит к првильному выводу, что пока нет единого ключа к решению юрисдикционных конфликтов, но многообразие правового регулирования и различные комбинации имеющихся законодательных возможностей обнаруживают потенциал для такого решения, в первую очередь, путем разработки соответствующей модели, дальнейшего развития территориального принципа (действия уголовного закона в пространстве), принятия соответствующих политических решений (с. 529).

Четвертая часть книги подготовлена профессором Альбином Эзером (с. 557574) и представляет собой основательный критический анализ модельных проектов регламентации механизма решения юрисдикционных конфликтов, а пятая часть (с. 597-616) содержит выводы, вытекающие из проведенного исследования в целом в виде соответствующего модельного проекта правового регулирования (на немецком и английском языках). Завершается монография сведениями о ее авторах (с. 617-620).

Участники проекта исходят из того, что споры о подведомственности и подсудности, то есть юрисдикционные конфликты, возникают при параллельном уголовном судопроизводстве по одному и тому же делу в нескольких странах. Это зачастую грозит несколькими уголовными преследованиями и даже несколькими наказаниями за одно и то же деяние, повышает риск межгосударственных конфликтов, вызывает рост расходов уголовной юстиции. На уровне Европейского Союза с 2009 г. действует правовой механизм избежания и урегулирования споров о подведомственности, включающий обмен информацией и консультации, обязанность государств-членов ЕС устанавливать контакты между соответствующими органами в случае возникновения ситуаций параллельного уголовного преследования. В то же время пока не будет достигнуто согласие о совместном осуществлении уголов- 
ного процесса по конкретному делу, у всех государств-членов ЕС сохраняется право продолжать расследование в соответствии с национальным правом.

Предлагается разработать проект Рамочного решения Европейского Совета о передаче уголовного судопроизводства и внести изменения в действующее Рамочное решение об избежание и разрешении споров о подведомственности. Следует согласиться с автором рецензируемой монографии, что главное заключается в обосновании перечня критериев, по которым государства-члены ЕС должны будут принимать решение о том, какое именно государство будет осуществлять уголовное преследование, и их иерархии. При этом сохраняется презумпция осуществления уголовного процесса в государстве, где находится основное место преступления (место совершения преступления и место окончания преступления), которая, однако, может быть, и нарушена, если имеются следующие обстоятельства, которые должны быть учтены: место, где причинен наибольший вред; существенные интересы потерпевших и обвиняемого (например, владение языком страны, где будет осуществляться уголовное преследование, возможности и условия ресоциализации и т.п.); место, где находятся значимые для дела доказательства; угроза безопасности для свидетелей; экономия процессуальных действий и расходов (возможность непрерывного судопроизводства, обеспечение присутствия свидетелей и обвиняемого ит.п.). При этом особое внимание авторы обоснованно обращают на принцип ограничения злоупотреблений, в соответствии с которым устанавливается запрет переноса уголовного судопроизводства в определенное государство по таким мотивам, что только в нем, возможно, его осуществление, например, из-за истечения сроков давности, амнистии или недопустимости доказательств в другом/других государствах. Таким образом, умышленный выбор наиболее выгодной юстиции с целью ухудшить положение обвиняемого рассматривается как злоупотребление правом.

Авторы проекта полагают, что при отсутствии соглашения между государствами окончательное решение о подведомственности уголовного дела должна решать трансграничная инстанция - Евроюст как основа будущей общеевропейской прокуратуры, планируемой в соответствии со статьей 86 Амстердамского договора об образовании $\mathrm{EC}$, подлежащий контролю со стороны Европейского Суда. В частности предлагается новый вариант статьи 15 Рамочного решения, согласно которому устанавливается срок - одна неделя, в течение которого государство может обжаловать решение Евроюста в Европейском Суде. В целях избежания возникновения споров о подведомственности с третьими странами, например США, Японией, Россией, и их разрешения авторы рекомендуют заключение и ратификацию международной конвенции аналогично действующему в Евросоюзе Рамочному решению.

Проведенной исследование, на наш взгляд, является не только основой для принятия международных правовых документов и улучшения ситуации в области предупреждения и разрешения юрисдикционных конфликтов, все чаще возникающих в наши дни, но и примером плодотворного сотрудничества юристов разных стран. Опубликование рецензируемой книги на русском языке могло бы послужить и совершенствованию уголовного и уголовно-процессуального законодательства, и улучшению взаимодействия между правоохранительными органами государств-участников конвенции по борьбе с организованной и иными видами транснациональной преступности, стороной которых является Российская Федерация. 
DOI: $10.7256 / 2226-6305.2015 .1 .13330$

При цитировании этой статьи сноска на dоі обязательна

Информация о литературе, периодических изданиях, сайтах / Sources used

\section{Библиография:}

1. А.Э. Жалиннский. Современное немецкое уголовное право. М.: Проспект, 2004. - 560 с

\section{References (transliterated):}

1. A.E. Zhalinnskii. Sovremennoe nemetskoe ugolovnoe pravo. M.: Prospekt, 2004. - $560 \mathrm{~s}$ 